\title{
UPAYA PEMANFAATAN PERKARANGAN RUMAH UNTUK BUDIDAYA TOGA DALAM MENGOPTIMALISASIKAN PENANGGULANGAN WABAH COVID-19 DI DESA SUNGAI JUNJANGAN.
}

\section{MILDA}

${ }^{1}$ Jurusan Agroteknologi, Fakultas Pertanian, Universitas Islam Indragiri, Tembilahan

Email: mildaimel89@gmail.com (082285747334)

\begin{abstract}
Coronaviruses are a large family of viruses that cause illness ranging from mild to severe symptoms. There are at least two types of coronavirus that are known to cause diseases that can cause severe symptoms such as Middle East Respiratory Syndrome (MERS) and Severe Acute Respiratory Syndrome (SARS). Coronavirus Disease 2019 (COVID-19) is a new type of disease that has never been previously identified in humans. The virus that causes COVID-19 is called Sars-CoV-2. Corona viruses are zoonotic (transmitted between animals and humans). This research was conducted with the method of distributing some ginger plant seeds to the community so that people can cultivate this ginger plant without requiring a large area of land and only needing a yard or a house terrace, so that it makes it easier for people to harvest it and process it into traditional herbal medicine that is beneficial to the body when the Covid-19 epidemic 19. In The Junjangan Village Community. In the development of this toga plant, there are several factors that influence the occurrence of a factor. The factors referred to in this are things that affect the resistance and development of toga development efforts so that they are still being developed until now. These factors include: capital management factors, production factors, demand factors and human resource factors (Poerwadarminta, 2002).
\end{abstract}

Keywords:TOGA, Covid 19, Junjangan Village

\begin{abstract}
Abstrak
Coronavirus adalah keluarga besar virus yang menyebabkan penyakit mulai darigejala ringan sampai berat. Ada setidaknya dua jenis coronavirus yang diketahui menyebabkan penyakit yang dapat menimbulkan gejala berat seperti Middle East RespiratorySyndrome (MERS) dan Severe Acute Respiratory Syndrome (SARS). Coronavirus Disease2019 (COVID-19) adalah penyakit jenis baru yang belum pernah diidentifikasi sebelumnyapada manusia. Virus penyebab COVID-19 ini dinamakan Sars-CoV-2. Virus corona adalah zoonosis (ditularkan antara hewan dan manusia). Penelitian ini di lakukan dengan metode pembagian beberapa bibit tanaman jahe kepada masyarakat agar masyarakat bisa membudidayakan tanaman jahe ini tanpa memerlukan lahan yang luas dan hanya memerlukan halam atau teras rumah, agar memudahkan masyarakat memanennya dan mengolahnya menjadi jamu tradisional yang bermanfaat bagi tubuh disaat pendemi covid-19. Dalam pengembangan tanaman toga ini terdapat beberapa faktor yang ikut mempengaruhi terjadinya sesuatu faktor.Faktor yang dimaksud dalam ini adalah hal-hal yang mempengaruhi terjadinya ketahanan dan perkembangan usaha pengembangan toga sehingga tetap di kembangkan sampai sekarang. Faktor-faktor tersebut seperti: faktor manajemen permodalan, faktor produksi, faktor permintaan dan faktor sumberdaya manusia (Poerwadarminta, 2002).
\end{abstract}

Kata kunci:TOGA, COVID 19, Desa Sungai Junjangan 


\section{PENDAhuluan}

Coronavirus adalah keluarga besar virus yang menyebabkan penyakit mulai darigejala ringan sampai berat. Ada setidaknya dua jenis coronavirus yang diketahui menyebabkan penyakit yang dapat menimbulkan gejala berat seperti Middle East RespiratorySyndrome (MERS) dan Severe Acute Respiratory Syndrome (SARS). Coronavirus Disease2019 (COVID-19) adalah penyakit jenis baru yang belum pernah diidentifikasi sebelumnyapada manusia. Virus penyebab COVID-19 ini dinamakan SarsCoV-2. Virus corona adalah zoonosis (ditularkan antara hewan dan manusia).

Penelitian menyebutkan bahwa SARS ditransmisikan dari kucing luwak (civet cats) ke manusia dan MERS dari unta ke manusia. Adapun, hewan yang menjadi sumber penularan COVID-19 ini sampai saat ini masih belum diketahui. Pandemi COVID-19 yang terjadi saat ini mau tidak mau memberikan dampak terhadap berbagai sektor.Pandemi COVID-19 yang terjadi saat ini mau tidak mau memberikan dampak terhadap berbagai sektor.Seperti pada sektor pertanian terutama TOGA (Tanaman Obat Keluarga).Pekarangan rumah sudah seharusnya dimanfaatkan untuk menanam berbagai jenis tumbuhan, baik itu tanaman hias, tanaman buah dan tidak ketinggalan adalah Tanaman Obat Keluarga (TOGA).Saat ini tanaman obat mulai banyak dilirik masyarakat sebagai alternatif untuk menjaga dan mengatasi berbagai masalah kesehatan.

Adanya TOGA di pekarangan rumah tentu saja akan sangat bermanfaat, baik nantinya digunakan sebagai obat tradisional yang sifatnya mencegah atau mengobati berbagai penyakit, sebagai bumbu pelengkap masakan atau menambah nilai estetika tersendiri jika ditanam dengan tertata rapi. Hal ini didukung oleh kebijakan Departemen Kesehatan RI tentang pengobatan tradisional seperti yang tercantum dalam UU No 23 tahun 1992 pasal 47 tentang pengobatan tradisional dan dalam Kepmenkes No 1076/SK /VII/2003 tentang peyelenggaraan pengobatan tradisional yang menggunakan tanaman obat-obatan. Indonesia sebagai negara kepulauan merupakan kawasan yang kaya dengan keaneka ragaman
hayati.Sampai saat ini telah diketahui sekitar 30.000 jenis tumbuhan yang tumbuhan liar maupun yang sudah dibudidayakan, sebagai tanaman obat tradisonal.Badan Pengawas Obat dan Makanan (POM, 2003).

Program pemerintah Kabupaten yaitu Gerakan Pembangunan Desa Mandiri (Gerbang Dema) salah satu pilarnya adalah memprioritaskan pembangunan yaitu peningkatan pertanian secara luas dan usaha pemberdayaan ekonomi keluarga, pengembangan tanaman obat keluarga melalui kelompok ibu-ibu Dasa Wisma, PKK di tingkat ibu-ibu rumah tangga dan dikelola oleh masing-masing desa, salah satu program desa yang dikembangkan oleh ibu-ibu PKK adalah tanaman obat keluarga (TOGA). Pengembangan TOGA bertujuan untuk meningkatkan pendapatan keluarga pengembangan TOGA dipengaruhi oleh banyak faktor, baik yang bersifat menunjang maupun menghambat

\section{TINJAUAN PUSTAKA}

\subsection{Landasan Teori}

Virus merupakan sebuah partikel yang masih belum diketahui dan dibicarakan statusnya apakah ia termasuk makhluk hidup atau benda mati. Dikatakan makhluk hidup karena virus dapat memperbanyak diri dalam tubuh dan dikatakan benda mati karena virus dapat dikristalkan. Para ahli biologi menetapkan bahwa virus merupakan organisme non-seluler karena ia tidak mempunyai kelengkapan seperti sitoplasma, organel sel dan tidak bisa membelah diri sendiri. Ada beberapa tokoh telah melakukan penemuan virus pertamanya seperti Dmitri Ivanovski (1892, Rusia) mengatakan bahwa ia mencoba menyaring getah tanaman yang sakit dengan filter bakteri sebelum disemprotkan ke tanaman sehat. Hasilnya, tanaman sehat tetap tertular. Ia menyimpulkan bahwa ada partikel yang lebih kecil lagi dari bakteri yang lolos saringan yang menularkan penyakit. Hal tersebut menyatakan bahwa virus berupa bakteri yang sangat kecil sehingga keberadaannya sangat sulit untuk dijangkau bahkan ia masih dapat lolos meskipun sudah diberikan disinfektan. Virus mempunyai bentuk 
yang berbeda-beda seperti ada yang berbentuk bulat, oval,memanjang, silindaris dan ada juga berbentuk $\mathrm{T}$. Variasinya pun bermacam-macam dari segi ukuran, bentuk dan komposisi kimiawinya. Untuk melihat virus harus menggunakan mikrosop elektron sebab virus ukurannya sangat kecil dibanding bakteri dan berkisar dari 0,02 mikrometer sampai 0,3 mikrometer.

Dalam proses perkembangbiakan virus membutuhkan metabolisme sel penjamur untuk membantu penggabungan virus lainnya. Sehingga virus dapat berkembangbiak dengan cepat didalam tubuh inang. Virus sendiri tidak melulu dapat menimbulkan penyakit di dalam tubuh akan tetapi ada virus yang memiliki peran mikroorganisme yang menguntungkan dan ada yang merugikan. Virus yang menguntungkan bagi tubuh adalah virus yang berperan penting dalam rekayasa genetika karena dapat digunakan sebagai pengganti gen (reproduksi DNA yang secara genetis identik). Misalnya virus yang digunakan dalam terapi gen terhadap manusia guna menyembuhkan penyakit gen (penyakit bawaan sejak lahir) seperti diabetes dan kanker. Sedangkan virus yang merugikan adalah virus yang dapat menyebabkan berbagai jenis penyakit pada makhluk hidup seperti manusia, tumbuhan dan hewan.Virus yang merugikan dan dapat menyebabkan penyakit adalah virus hepatitis, virus hepatitis A (HAV), Human Immunodeficiency Virus (HIV) dan sebagainya.

Covid-19 atau Coronavirus Disease 2019 adalah penyakit baru yang dapat menyebabkan gangguan pernapasan dan radang paru.Covid-19 disebabkan oleh infeksi Severse Acute Respritory Syndrome Coronavirus 2 (SARS-CoV-2).Coronavirus pertama kali di temukan di Wuhan, China tepatnya di pasar hewan Huanan, Wuhan.Umumnya masyarakat Wuhan terbiasa mengkonsumsi daging hewan liar, mereka bahkan menjual hewan tersebut dalam kondisi hidup sehingga dari mengkonsumsi daging hewan liar tersebut masyarakat Wuhan mengalami gejala yang akhirnya dinyatakan positif coronavirus.Sebab coronavirus awalnya menular dari hewan ke manusia namun kemudian diketahui bahwa coronavirus juga menular dari manusia ke manusia. Awal mulanya kemunculan coronavirus diduga merupakan penyakit pneumonia karena memiliki gejala yang sama seperti flu pada umumnya. Akan tetapi virus corona ini mampu berkembang sangat cepat sehingga mengakibatkan infeksi lebih parah dan gagal organ.

Gejala yang dimunculkan umumnya sangat beragam seperti batuk, pilek, nyeri tenggorokan, nyeri otot, nyeri kepala dan yang sangat parah adalah pneumonia atau sepsis.Sehingga coronavirus diartikan sebagai kumpulan virus yang bisa menginfeksi system pernapasan. Selain disebabkan oleh virus SARS ditemukan juga virus penyebab lainnya yaitu virus MERS atau Middle-East Respritory Syndrome, kedua virus itu termasuk kedalam kelompok virus yang sama yaitu coronavirus. Covid-19 dengan SARS dan MERS memiliki perbedaan yaitu kecepatan penyebaran dan keparahan gejala yang ditimbulkan. Virus ini dapat menyebar ke siapa saja, akan tetapi akan sangat berbahaya jika coronavirus terjadi pada orang yang lanjut usia, ibu hamil dan orang yang memiliki penyakit tertentu seperti perokok, asma, kanker dan tentu saja pada orang yang memiliki imunitas tubuh yang lemah.

Karena coronavirus ini mudah menyebar dan menginfeksi siapapun, bahkan tenaga medis pun dapat dengan sangat mudah terinfeksi coronavirus yang ditularkan dari pasien pengidap coronavirus diperlukannya APD untuk para tenaga medis agar mereka terhindar dari penyakit coronavirus tersebut.

\section{METODOLOGI PENELITIAN}

Secara Administratip Desa Sungai Junjangan Termasuk Dalam wilayah Kecamatan Batang Tuaka Kabupaten Indragiri Hilir Propinsi Riau yang Terletak dibagian utara, Merupakan salah satu desa yang memiliki potensi ekonomi berkembang didukung olehInsprastuktur Desa Sungai Junjangan.Dilihat Secara umum Keadaanya merupakan dataran rendah yang di aliri sungai batang tuaka.Dan beberapa anak sungai lainya..

Penelitian ini di lakukan dengan metode pembagian beberapa bibit tanaman jahe kepada masyarakat agar masyarakat bisa membudidayakan tanaman jahe ini tanpa memerlukan lahan yang luas dan hanya memerlukan halam atau teras rumah, agar memudahkan masyarakat memanennya dan mengolahnya menjadi jamu tradisional yang bermanfaat bagi tubuh disaat pendemi covid-19.

\subsection{Sejarah Desa}


Desa sungai Junjangan merupakan salah satu Desa yang ada di Kecamatan Batang Tuaka yang termasuk Desa tua. Karna sampai saat ini jumlah Kepala Desa yang pernah memimpin H.Hasan, Buyasir Kasmurejo, Suratrman Marzuki Ahmadi, Hj. Lisnawati, Pj. Ependi Mukhtab, SH, Haryadi

Adapun Desa sungai Junjangan dahulu kala sebuah pemukiman masyarakat yang hijau hasil panen petani berlimpah. Dan pada zaman penjajahan banyak putra putri daerah yang menjadi korban dan selanjutnya Pada tahun 1950 an Masyarakat mengangkat tokoh sebagai pengayom yaitu Bapak $\mathrm{H}$. Hasan dikala kepemimpinan beliau ada beberapa kejadian di sektor keamanan maka masyarakat kembali mengangkat Bapak Buyasir KasmoRejo (Bapak Wali) beliau memimpin lebih kurang 32 Tahun. Dikala itu beliu membawa rasa aman bagi masyarakatnya dan pada tahun 1985 pada tahun itumasyarakat kembalidihadapkan sebuah masalah yaitu kejolak alam (banjir yang berkepanjangan sehingga sebagian masyarakat meninggalkan Desanya dan yang bertahan merubah mata pencaharianya yang senula bertani menjadi perambah hutan. Hingga beberapa tahun kemudian masyakat kembali menggarap lahanya sampai saat ini dan pada tahun 1971 Pak walibersama masyarakat bahu membahu mendirikan kantor pelayanan masyarakat dengan dana sewadaya yang sebelumnya pelayanan masyarakat dirumah pak wali. kantor yang di bangun pada saat itu sampai saat ini masih berfungsi sebagai pelayanan masyarakat walaupun sudah di bangun Kantor Desa yang baru.

\subsection{Letak Geografis}

Letak geografi

Junjangan ,letak diantara : Sebelah Utara, Desa Rambaian Sebelah Selatan Desa Tanjung Siantar,

Sebelah Barat Desa Sebatu

Sebelah Timur Desa Sungai Rawa

a) Luas Wilayah Desa: $10.000 \mathrm{Ha}$

b) Orbitasi

Jarak ke ibu kota kecamatan terdekat 22 KM

Lama jarak tempuh ke ibu kota

kecamatan : \pm 2 Jam, Jarak ke ibu kota kabupetan $13 \mathrm{KM}$

Lama jarak tempuh ke ibu kota

Kabupaten : \pm 1 Jam, Jumlah penduduk berdasarkan jenis kelamin. Kepala
Keluarga

781 KK. Laki-laki 1840

Orang Perempuan 1637 Orang

\section{HASIL DAN PEMBAHASAN}

Pada hakekatnya upaya pengobatan tradisional di Indonesia merupakan bagian dari budaya bangsa yang diturunkan dari generasi terdahulu ke generasi berikutnya, baik secara lisan maupun secara tertulis/dibukukan.Sementara ilmu pengobatan itu sendiri ada yang berasal dari warisan nenek moyang dalam negeri dan dari luar negeri.

Toga ialah tanaman Obat Keluarga, dahulu disebut sebagai "Apotik Hidup".Dalam pekarangan atau halaman rumah di tanam beberapa tanaman obat yang digunakan secara empirik oleh masyarakat untuk mengatasi penyakit atau keluhan- keluhan yang dideritanya. Beberapa tanaman obat telah dibuktikan efek farmakologinya pada hewan dan beberapa tanaman telah dilakukan uji klinik. TOGA adalah singkatan dari tanaman obat keluarga, yaitu berbagai jenis tanaman yang dibudidayakan baik di halaman, pekarangan rumah, ladang atau di kebun. Tanaman tersebut sebagai Apotek Hidup yang dapat memenuhi keperluan keluarga akan obat-obatan. Jenis tanaman yang dibudidayakan sebagai TOGA adalah tanaman yang tidak memerlukan perawatan khusus, tidak mudah diserang hama penyakit, bibitnya mudah didapat, mudah tumbuh dan tidak termasuk jenis tanaman terlarang dan berbahaya/beracun.

Pemanfaatan TOGA lazimnya untuk pengobatan gangguan kesehatan keluarga menurut gejala-gejala umum seperti demam panas, batuk, sakit perut, gatal-gatal (Ridwan. 2007). melalui instansi terkait seperti Dinas Kesehatan dengan kerjasama PKK dapat melakukan sosialisasi terhadap program TOGA bagi menunjang upaya peningkatan kesehatan oleh masyarakat secara optimal.

\section{KESIMPULAN DAN SARAN}

\subsection{Kesimpulan}

Tanaman obat merupakan salah satu unsur penting dalam upaya pelaksanaan pengendalian kesehatan. Tanaman obat sudah dikenal sejak dahulu dalam pengobatan tradisional, namun pengunaannya sebagai bahan baku belum dimanfaatkan secara optimal sedangkan upaya yang telah dilakukan masih tertuju kepada khasiat dan kegunaannya saja. Pada masa pendem tanaman obat sangat di perlukan sebagai 
bagi masyarakat desa ( rumah tangga )

sistem imun tubuh d kekebalan tubuh dengan cara di olah menjadi jamu.

Toga ialah tanaman Obat Keluarga, dahulu disebut sebagai "Apotik Hidup".Dalam pekarangan atau halaman rumah di tanam beberapa tanaman obat yang digunakan secara empirik oleh masyarakat untuk mengatasi penyakit atau keluhan- keluhan yang dideritanya. Beberapa tanaman obat telah dibuktikan efek farmakologinya pada hewan dan beberapa tanaman telah dilakukan uji klinik. Penggunaan tanaman obat tradisional hingga sekarang masih sangat diwarnai oleh penggunaan sendiri oleh masyarakat, yakni untuk "self medication".Bentuknya adalah yang langsung dapat diminum, seperti jamu gendong atau jamu dari penjual.di kioskios. Selain itu, juga jamu berbungkus yang dibuat oleh industri rumah tangga.Diantara tumbuhan obat tradisional banyak yang hampir punah, sehingga kalau sewaktu-waktu dibutuhkan sulit diperoleh.

Padahal khusus meningkatkan penggunaan tumbuhan obat tradisional, pemerintah telah menggalakan Tanaman Obat Keluarga (TOGA) yang telah dimasyarakatkan oleh Lembaga Tanaman Obat Keluarga yang telah dimasyarakatkan oleh Lembaga Swadaya Masyarakat (LSM) dalam hal ini antara lain oleh PKK yang sekaligus berfungsi menghijaukan lingkungan atau melestarikan sumberdaya hayati. Namun program TOGA nampaknya masih belum berhasil, sehingga perlu ditingkatkan permasyarakatannya.

Dalam pengembangan tanaman toga ini terdapat beberapa faktor yang ikut mempengaruhi terjadinya sesuatu faktor.Faktor yang dimaksud dalam ini adalah hal-hal yang mempengaruhi terjadinya ketahanan dan perkembangan usaha pengembangan toga sehingga tetap di kembangkan sampai sekarang. Faktor-faktor tersebut seperti: faktor manajemen permodalan, faktor produksi, faktor permintaan dan faktor sumberdaya manusia (Poerwadarminta, 2002).

\subsection{Saran}

1. Berikan bantuan modal dan penyuluhan kepada masyarakat tentang pentingnya tanaman obat.

2. Menjadikan tanaman obat ini sebagai penghasilan tambahan

\section{DAFTAR PUSTAKA}

1. Anonim, 2005, "Teknik Budidaya Tanaman Obat" , Satuan Kerja Pembina dan Pengembangan Hortikultura, Kabupaten Majene.

2. Anonim, 2013.Kumpulan bunga mawarku

(http://kumpulanbungamawarku. blogspot. com/2011/04/faktorfaktor-yang-mempengaruhi.html) diakses tanggal 2 / 92013 pada jam 7: 00.

3. Boediono (1992), "Tanaman Obat Indonesia", Direktorat Jenderal Pengawasan Obat dan Makanan.Jakarat.

4. Djawanto, 2008. "Statistik Non Parametrik", Jogjakarta :BPFE

5. Dzulkarnain, H.B dkk. 2009. Tanaman Obat Keluarga. Jilid 1 \& jilid 2.PT. Intisari MediaTama. Jakarta.

6. Krugman and Obstfeld (2001), "Lima Tahun Penelitian dan Pengembangan Pertanian", Deptan RI.

7. Kotler, P. 2007. Manajemen Pemasaran. Lembaga Penerbitan Fakultas Ekonomi Universitas Indonesia. Jakarta

8. Mubyarto, 1994, "Pengantar Ekonomi Pertanian", LP3ES, Jakarta

9. Marshall, A. (Ed). 2006. "Pengobatan Alternatif".PT. Dian Rakyat. Jakarta

10. Poerwadarminta, 2002).." Budidaya Tanaman Obat Secara Organik" . Agromedia Pustaka. Jakarta

11. Ridwan. 2007. "Pemanfaatan Tanaman Obat Keluarga", Pusat Perbukuan DEPTAN. Jakarta

12. Soekartawi, 2001, "Pengantar Agroindustri", Kata Grafindo Persada, Jakarta.

13. Supriyanto, 2006." Proses Pengolahan Tanaman Obat", Jakarta. Tim Lentera

14. Badan POM, 2003). kebijakan Departemen Kesehatan RI tentang pengobatan tradisional seperti yang tercantum dalam UU No 23 tahun 1992 pasal 47 tentang pengobatan tradisional dan dalam Kepmenkes No 1076/SK /VII/2003 tentang 
peyelenggaraan pengobatan

tradisional yang menggunakan

tanaman obat-obatan. 